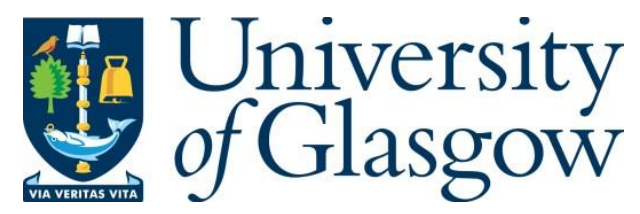

Garkavenko, V. and Tiberghien, G. (2015) ICT diffusion and the digital divide in tourism: Kazakhstan perspective. In: Kantarci, K., Uysal, M. and Magnini, V.P. (eds.) Tourism in Central Asia: Cultural Potential and Challenges. Series: Advances in hospitality and tourism book. Apple Academic Press: Oakville, pp. 287-306. ISBN 9781771880558.

There may be differences between this version and the published version. You are advised to consult the publisher's version if you wish to cite from it.

\title{
http://eprints.gla.ac.uk/113189/
}

Deposited on: 9 June 2017

Enlighten - Research publications by members of the University of Glasgow http://eprints.gla.ac.uk 


\title{
CHAPTER 12
}

\section{ICT DIFFUSION AND THE DIGITAL DIVIDE IN TOURISM: KAZAKHSTAN PERSPECTIVE}

\author{
VLADIMIR GARKAVENKO and GUILLAUME TIBERGHIEN
}

\subsection{ICT AND TOURISM}

Information and communication technologies (ICTs) can be defined as manufactured products and services intended to enable or stimulate information processing, communication, use of electronic means to detect, measure or record physical phenomena or to control physical processes (OECD, 2001). Starting from the first Computer Reservation System (CRS) in the 1950s, information technology has both transformed the way in which customers plan and purchase their holidays and how the tourism industry promotes and sells its products and services.

The fast and efficient exchange of information between the players in the tourism is essential for efficient distribution, sales and customer service. This information dependence has placed the industry at the forefront of ICT adoption (Mason and Milne, 2002). The Internet and electronic commerce development in the late 1990s and their adoption by tourism as one of the prime business to business (B2B) and business to consumer (B2C) applications has changed the industry and has shifted the traditional way tourism and travel products are distributed (Buhalis, 2003; O'Connor, 1999; O'Connor and Frew, 2002).

Tourism suppliers (particularly airlines, car rental firms and hotel chains) have taken advantage of the new opportunities offered and have developed e-commerce applications by allowing users to directly access their reservation systems. This includes single supplier providers such as British Airways (britishairways.com), Marriott Hotels (marriot.com), Avis (avis.com), and multi-supplier web pages that support airlines (opodo.com; orbitz.com). In addition, destinations have developed management systems to distribute their smaller properties and present the destination as a holistic entity (tiscover.com; holland.com). A number of web-based TAs have also emerged (e.g., Expedia.com, ebookers.com, Travelocity.com), and some off-line agencies have developed on-line provision (thomascook.com; lunnpoly.com). Moreover, Internet portals (Yahoo, Altavista, Excite) and vertical portals (or vortals - web site portals that provide information and resources for a particular industry) have also developed on-line travel distribution systems, often by sourcing their content from external on-line agents and suppliers (ski.com; golfonline.com; tennis.com). 
The effective use of ICT is pivotal in the tourism industry. Commentators have noted that "A whole system of ICT is being rapidly diffused throughout the tourism industry and no player can escape its impact" (Poon, 1993, p.123).

Unlike durable goods, intangible tourism services cannot be physically displayed or inspected at the point of sale before purchasing. They are bought before the time of their use and away from the place of consumption. Hence they depend exclusively upon representation and descriptions, provided by the travel trade for their ability to attract consumers. Timely and accurate information, relevant to consumers' needs, is often the key to satisfaction of tourist demand. Therefore, ICT provides the information backbone that facilitates tourism (Buhalis, 1998, p. 411).

The cyberspace travel market is characterized by steady growth in different countries. Online sales accounted for $14.4 \%$ of the American market - a massive shift to online travel, which is being repeated in other parts of the world. However, online services have yet to take off in the huge Asian market. Global Internet users reached 1.4 billion, of which $65 \%$ was located in Asia, by 2009, according to Yahoo! South-east Asia at the Travel Distribution Summit Asia 2006 (European Travel Commission-New Media Review, 2006). Yahoo! South-east Asia believes that Asia Pacific is expected to account for 423 million Internet users, excluding China, of the total 1 billion base. In Europe online services were growing rapidly (Economist.com, 2005). In 2005, the number of visitors to travel websites in America grew by $12.7 \%$. This compares with an increase of almost $30 \%$ in the number of visitors to British websites.

The wider availability of e-tickets should speed the development of online travel everywhere. It spread even faster once paperless tickets became more widely accepted for socalled 'interline agreements,' in which a ticket issued by one carrier is valid on another carrier for part of the journey (Economist. com, 2005). Furthermore, all major airlines switched to eticketing by 2007 .

There are, of course, variations between countries, with the UK accounting for $39 \%$ of the European on-line travel market followed by Germany in second place at $23 \%$. According to the research, Germany had the fastest growing on-line travel market in Europe; the breakdown by type of service was: air travel $57.3 \%$, hotels $14.4 \%$, package tours $16.5 \%$, rail $8.4 \%$, rental cars $2.1 \%$, and other services $1.5 \%$ (Marcussen, 2004).

Different sectors of the tourism industry are characterized by different levels of ICT adoption. Airlines realized fairly early the need for efficient, quick, and inexpensive systems. In 1962, American Airlines introduced its Sabre Computerized Reservation System (CRS), a project that was described as a technical marvel (French, 1998; O'Connor, 1999). Subsequently, the CRS expanded rapidly into a gigantic computerized network. In the 1990s, 
CRS evolved into Global Distribution Systems (GDS), which offered a wide range of tourism products and provided a mechanism for communication between principals and travel agencies. GDSs effectively became travel supermarkets offering information and reservation capabilities for the entire range of travel products, including accommodation, car rentals and schedules for nonair transport. GDSs are at the heart of airline operational and strategic agendas as they control and distribute the vast majority of airline seats (Buhalis, 2004).

The development of the world wide web (www) in the late 1990s provided both a challenge and an opportunity for airlines (American Airlines, 2000; French, 1998; Smith \& Jenner, 1998; Buhalis, 2000a,b). By 1998, most airlines already had web sites, which not only informed consumers but also enabled itinerary building, fare construction, and reservations. In turn, this enabled interactivity with consumers and the development of relationship marketing strategies. It also assisted airlines in launching another communication and purchasing channel to reduce the power and costs of conventional intermediaries.

Overall, it would appear that the establishment of new distribution channels by airlines in the Asia-Pacific region is following recent trends elsewhere - but will more likely be similar to those in Europe than in the US.

The development of the Internet has made information easily accessible to consumers, and has therefore established a direct link between consumers and suppliers. As a result, traditional travel distribution channels are changing rapidly. A major feature of this change is "disintermediation," with principals such as airlines, hotels and rental car chains bypassing intermediaries to sell directly to consumers. A number of web-based travel agents have also emerged (Expedia.com, Travelocity.com) while off-line agencies have developed their online provision. Internet portals (Yahoo, Altavista, Excite) and vertical portals (or vortals) have also developed on-line travel distribution, often by sourcing their travel contents from external online agents and suppliers.

On-line travel agencies are moving into Asian markets. Travelocity, one of the two leading on-line agencies in Canada, Europe and the US, is reported to be establishing an on-line distribution system in Asia (Kirby, 2001).

There has been little research on the impact of ICT on the tourism industry outside European and North American settings. Some research has been done on the ICT impact on the travel agent sector in Singapore (Tse, 2003) and in New Zealand (Garkavenko, 2008a, 2008b). In our previous research (Garkavenko et al., 2010; Rybina, and Garkavenko, 2009; Garkavenko et al., 2009a; Garkavenko et al., 2009b; Garkavenko et al., 2010) a clear digital disparity was established between the global travel industry and Kazakhstan's tourism industry. The need for countries to measure and bridge domestic and international digital divides is a general consensus in academic circles (Minghetti and Buhalis, 2010). However, 
there is very little research focusing on the reduction of the digital gap between tourism markets and destinations within and between countries. Studies on the digital divide in tourism appear particularly relevant in countries where tourism is considered to be very important for socioeconomic development. The Kazakhstan travel industry is emerging. At this stage there is a lack of academic research into the industry in general and specifically on any ICT impact or its integration into the global travel industry system. The study aims to analyze ICT adoption by the Kazakhstan tourism industry and the digital divide in the industry and its implementation for global tourism industry integration.

Business and academic literature on Kazakhstan Internet and ICT adoption, literature on Kazakhstan tourism industry as well as official statistics were used as sources of the secondary data. The researchers also summarized their primary data on the Kazakhstan's tourism industry (Garkavenko et al., 2009a,b, 2010a,b; Garkavenko and Tiberghien, 2011a,b; 2012; Rybina and Garkavenko, 2009; Tiberghien and Garkavenko, 2011). A series of research projects supported by KIMEP University (Almaty, Kazakhstan) have been conducted on different aspects of the Kazakhstan's tourism industry-its structure, ICT adoption by different tourism industry sectors, consumer adoption of ICT and readiness to go on-line for ticketing and bookings.

\subsection{METHODOLOGY}

The presented exploratory study adopts qualitative methods. The goal of qualitative research is to locate the understanding of a phenomenon within the context of another (Oppenheim, 1992; Rubin and Rubin, 2005; Silverman, 2004; Seymour, 2001).

The research uses two types of data collection and analysis: case study and in-depth interviews. Case studies are broadly used in tourism research (Aneshensel, 2002; Beeton, 2005; Horner, and Swarbrooke, 2004). Unlike more specifically directed research, case studies investigate a problem that seeks a holistic understanding of the event or situation in question. According to Flyvbjerg (2006), a case study can be used to both generate and test hypotheses. Suggested sources of secondary data are business and academic literatures on Kazakhstan Internet and ICT adoption, literature on Kazakhstan tourism industry, official statistic as well as ICT use by tourism industries in other countries.

It is well accepted that in-depth interviews are applied to enhance knowledge of newly emerging, under-researched phenomena (Kwortnik, 2003). Until the researcher is relatively clear on what is to be studied and how, the objective of the interview should be discovered, and enhanced understanding of the phenomena. Such an understanding is derived from data grounded in the informant's experience-what they say about what they did, felt, or thought. 
A total of 30 industry specialists were interviewed. A sampling method was adopted that enabled the researcher to include a cross-section of tourism businesses, including franchise/chain retail operations, small independent enterprises, and wholesalers. Each the indepth interview was about an hour long each. The interviews were designed to produce a considered response to certain issues including: background about the firm, the use of ICT and associated issues.

In addition a total of 50 in-depth interviews were held with prospective consumers. A judgmental technique was applied to select interviewees. The criteria of selection were at least one trip (overseas and/or domestic) per year, and at least basic PC skills. A brief questionnaire preceded the interview that included demographic data, and PC skills. The interview was focused on the questions: PC and mobile phone ownership, general attitude towards PC, buying on-line, usage of the Internet in searching of the information and in preparing, booking and buying a trip, and attitude towards TA.

Notes were taken during the interviews, which were also taped recorded and summarized. Subsequent analysis of the interviews was employed to identify common themes.

\subsection{KAZAKHSTAN TRAVEL INDUSTRY AND ICT DIFFUSION}

Before the collapse of the Soviet Union, the Kazakhstan's travel industry was integrated into the Soviet Union under Intourist (a contraction of the Russian words for 'foreign tourist'). Intourist was responsible for managing the great majority of foreigners' access to, and travel within, the Soviet Union and grew into one of the largest tourism organizations in the world. Intourist also owned its own hotels, destinations and means of transport, Travel Agencies, Tourist Offices and transport agency in one large enterprise. Sputnik was another big travel agency in the Soviet Union, responsible for inbound and outbound youth tourism and Intourbureau was organizing the trips for trade unions' members. After the 1990s' perestroika, those agencies left Kazakhstan and the tourism industry was left to develop its own businesses and infrastructure.

The development of Kazakhstan's tourist industry began with so called "shopping tours"- organized trips from Almaty, the former capital, to Turkey, China, Emirates and Pakistan. Multiple travel agencies formed spontaneously to organize charter trips, which led to further agencies forming, and selling air tickets. These were mainly small businesses under the auspices of banks and other corporate organizations to service their own business-trip needs. So called "seasonal" tour companies also sprang up to take domestic tourists to summer destinations such as Issuk Kul Lake (Kyrgyzstan) or to winter attractions like the Medeo (Kazakhstan) skating rink. 
At that time there was no one official carrier and private airlines were organizing charters and regular flights abroad. In February 2004 Air Astana became the national carrier after the government closed Air Kazakhstan. Currently they service 21 domestic and 23 international destinations. The airline is a joint venture owned by the Government of the Republic of Kazakhstan (who hold 51\%) and BAE Systems of Britain (a British firm of defense and airline contractors who hold 49\%). Kazakhstan's private airlines such as Scat and Sayakhat were left mainly with the niche market servicing private clients, cargo or charter tours.

According to official statistics, there were 16.6 million tourists in Kazakhstan in 2010. Twelve million were domestic and outbound tourists. There are 1250 registered tourism businesses in Kazakhstan.

According to our original research data (Garkavenko et al., 2009a, 2009b, 2010a, 2010b, 2011a, 2011b, 2012; Kadyrova et al., 2011) more than 95\% of tourism businesses in Kazakhstan are travel agencies. Almaty is the biggest urban center where the majority of travel businesses are situated. Before the financial crisis, there were about 800 Travel Agencies. They were mainly small businesses - from 3 to 10 employees, often family-owned and operated. According to Kazakhstan's legislation, one must be licensed in order to operate as a travel agent or tour operator. The Travel Agencies' main activity is selling holiday packages for groups. Seasonal tourism organizations also still exist, operating without licenses in summer for lakeside holidays or in winter for skiing. The structure and function of these agencies are rudimentary — just an organized bus, often with a nonprofessional guide. These agencies work with domestic tourists and such 'wild' tours meet strong opposition from licensed travel agencies.

Very often Travel Agents are acting as operators trying to develop their own tour packages to fill the gaps in infrastructure and to promote tourist destinations. These agencies are mainly concerned with outbound tours, although some handle both outbound and inbound tourists. For instance, an agency would sell a package tour to Turkey, but also organize cultural and food tours in the country. Outbound Travel Agencies prefer to liaise directly with foreign partners representing their own facilities like hotels and resorts. These agencies market themselves mainly at international travel fairs in Europe and Asia.

An average travel agent cannot afford to sell airline tickets directly — the airlines' deposits are too expensive - so they prefer to purchase fares through bigger agencies. Approximately 30-40 Travel Agents in Almaty have a distributor's agreement with the airlines.

According to our research on TA businesses in Almaty (Garkavenko et al., 2009a, 2009b, 2010a, 2010b, 2011a, 2011b, 2012), not all agencies have access to the Global Distribution System (GDS). If they do it is Amadeus. Travel agents often are not aware of any other GDS or Computer Reservation System (CRS). The majority of the travel agents uses the Internet 
for e-mails. If an agency has a website - it is only for the web presence - the majority of websites are not functionally active. Founders and owners of travel agencies are entrepreneurs with no special education in tourism. Personnel are drawn from such former occupations as engineering or political activists etc. However, a new type of agency is on the rise- on-line Travel Agencies. Kazakhstan operates a scholarship program known as Bolashak whereby graduate students are sent abroad on government grants to complete their education in different fields. Young postgraduates bring back international trends to the country. One such trend is online commerce and business. One online travel business owner believes that even now the country has a market for online commerce — in young people, the well-traveled and the well-off, white-collar strata. However, the majority of TAs believes that there is no demand for on-line services; they believe marketing is not essential; this is especially true in family-run small TA with loyal clientele. Regarding prospective consumers, TAs think that clients differ in terms of ICT readiness, but it can be taken as true that a traveler is more sophisticated and Internet savvy nowadays and is likely to do a lot of research on the Internet.

The data on ICT adoption by TA in Kazakhstan is summarized in Table 1.

Table 1. TA-ICT adoption.

\begin{tabular}{|l|l|}
\hline \multicolumn{1}{|c|}{ ICT adoption } & \multicolumn{1}{c|}{ Status } \\
\hline Connection to global systems & No GDS/CRS for the majority of TAs \\
\hline Internet use & Mainly for e-mails, rudimentary web presence \\
\hline ICT perception & No demand for on-line services \\
\hline Overall ICT adoption & Low \\
\hline
\end{tabular}

There are several big travel operators such as KazTour (Kazakh owned), Tez Tour (Russia/Ukraine), Zhana Nur (Kazakh ownership), On Travel (with Bulgarian ownership) and Gulnar Tour (Kazakh/Turkish ownership). The characteristic feature of Kazakhstan's Tourist Operator business is to sell directly to consumers. Operators normally do not have any agency agreement with travel agents, although an exception is Tez Tour from Russia. Its relationships are more structured - they work with and sell tours only through travel agencies. This more structural approach earns them loyalty from their agents. Tez Tour forms packages in every country they work - they have branches in Turkey, for instance. Tez Tour also has its own airplane (Sky Bus) and performs charter flights. They also brought to Kazakhstan "last minute" packages with low prices. The Internet adoption is reasonably high especially in TO with foreign participation - Kaztour, Tez Tour, Gulnar Tour, Zhana Nur, On Travel. ICT adoption by Kazakhstan TO is summarized in Table 2 . 
Table 2. ICT adoption by TO in Kazakhstan.

\begin{tabular}{|l|l|}
\hline \multicolumn{1}{|c|}{ ICT adoption } & \multicolumn{1}{c|}{ Status } \\
\hline Connection to global systems & Amadeus only \\
\hline Internet use & E-mails, web presence, B2B \\
\hline ICT perception & Necessary tool \\
\hline Overall ICT adoption & High \\
\hline
\end{tabular}

The Hospitality industry in Kazakhstan is presented by various types of hotels-from small family operated to big international chains such as Intercontinental, Hyatt, Rixos, Royal Tulip. ICT diffusion by hospitality industry varies from high in international chains (GDS, front and back stage systems, often CRM) to low in small hotels with old systems of running business (phone bookings, direct orders from TA and TO). ICT adoption by hotels in Kazakhstan is summarized in Table 3.

Table 3. Hotel industry and ICT adoption.

\begin{tabular}{|l|l|}
\hline \multicolumn{1}{|c|}{ ICT adoption } & \multicolumn{1}{c|}{ Status } \\
\hline Connection to global systems & GDS, front and back stage systems, often CRM \\
\hline Internet use & $\begin{array}{l}\text { Variable, high in international franchises and chains, low in } \\
\text { small local hotels }\end{array}$ \\
\hline ICT perception & Necessary tool for international chains, franchises \\
\hline Overall ICT adoption & Variable \\
\hline
\end{tabular}

Destinations in Kazakhstan do not have a very strong presence on the web. Only websites of big cities such as Almaty or Astana can be found. Smaller cities and especially the towns and local communities in rural areas do not have any websites because very often there is no Internet access. Some destinations in rural locations are trying to have more exposure on the web with the help of international experts (Garkavenko and Tiberghien, 2011, 2011a). Thus, there is a huge disparity between cities and rural areas in terms of Internet and PC diffusionhigh adoption in big cities and very low in rural and small town areas. Data on ICT adoption by tourism destinations in Kazakhstan is summarized in Table 4.

Table 4. Destinations and ICT adoption. 


\begin{tabular}{|l|l|}
\hline \multicolumn{1}{|c|}{ ICT adoption } & \multicolumn{1}{c|}{ Status } \\
\hline Websites & $\begin{array}{l}\text { Only in big cities. Small towns and local communities do not } \\
\text { have websites and very often Internet access }\end{array}$ \\
\hline ICT perception & Variable \\
\hline Overall ICT adoption & Variable \\
\hline
\end{tabular}

Regarding airlines - the national carrier Air Astana has a monopoly on flights in sectors through Asia. $51 \%$ of its shares belong to the state and $49 \%$ belongs to the BAE Systems in Great Britain. It has 3000 employees, including 100 flight staff; it has 21 aircraft. Air Astana sells tickets through its call centers and own travel agencies as well as through its website. It also has distributor agreements with some major travel agencies. Other companies such as Sayakhat offered (ceased operations in 2005) and Scat offers charter flights. Smaller airlines also exist, serving mainly private clients. Kazakhstan's airlines follow the international tendency in terms of ICT adoption. Data on airlines ICT adoption is summarized in Table 5.

Table 5. ICT adoption by Kazakhstan airlines.

\begin{tabular}{|l|l|}
\hline \multicolumn{1}{|c|}{ ICT adoption } & \multicolumn{1}{c|}{ Status } \\
\hline $\begin{array}{l}\text { Connection to global } \\
\text { systems }\end{array}$ & GDS, CRS \\
\hline Internet use & High B2B, only 2\% ticketing on-line, strong web presence \\
\hline ICT perception & Necessary tool \\
\hline Overall ICT adoption & Very high \\
\hline
\end{tabular}

\subsection{ICT ADOPTION BY KAZAKHSTAN CONSUMERS}

Tourism is a dynamic system that must respond quickly to significant environmental changes. Those changes in the international travel market have been introduced by ICTs, which have had an impact not only on suppliers but also on consumers. A new more knowledgeable and sophisticated consumer is emerging who is familiar and comfortable with new technologies such as the Internet, interactive digital television, and mobile phone services or m-commerce (Buhalis and Licata, 2002; Minghetti \& Buhalis, 2010; O’Brien, 1999; Rybina and Garkavenko, 2009).

Travellers are also increasingly gathering travel information themselves, forming their own customized holiday packages and making their own bookings. Inevitably, this leads to elimination of the non-value-added segments of the tourist service system. Therefore, changes 
in market conditions and in tourists' behaviors have created a gap between service suppliers and the volatile demand side of the industry. The development of the Internet has made information easily accessible to consumers and has therefore established a direct link between consumers and suppliers.

There have been dramatic advances in mobile data technologies that allow services to be delivered to a device such as a mobile phone or palm computer (O'Brien, 2002). Consumer adoption of the digital lifestyle differs from country to country (Morrisette et al., 1999). For instance, in 2009, B2C online travel sales reached over $\$ 90$ billion in the USA alone (eMarketer, 2009). In 2013, it is expected that nearly $70 \%$ of the population will be online, which amounts to 221 million people. Retail e-commerce also boomed in Europe during 2008-for instance, in France, according to the Federation du E-commerce et de la Vente à Distance (FEVAD), online sales rose nearly 30\%, reaching Euro 20.1 billion (Karin von Abrams, 2008). In Europe, a survey carried out by the computer company IBM and the intelligence unit of the British magazine 'The Economist' indicated that four Nordic countries (Denmark, Sweden, Norway, Finland) and the UK were the most frequent users of the Internet (Economist.com, 2005). According to the Internet market analysis by ROMIR Monitoring (2009), the Kazakhstan and Russian Internet markets are the fastest growing in Europe.

Thus, the travel market is affected not just by the initiatives of principals but also by high levels of ICT adoption by consumers. Increasingly, sophisticated and price conscious consumers have combined with the forces of globalization and electronic commerce to create new challenges for tourism businesses (Dean et al., 2002).

There is inconsistent data on ICT diffusion in Kazakhstan. Different statistic agencies give different figures on PC penetration and Internet adoption (Table 6). The figures on the PC and Internet adoption vary between 15 and 34 percent of the population with only $16 \%$ connected to the broadband. The Ministry of Communication and Information in Kazakhstan has announced that it intends to achieve $100 \%$ broadband population coverage by 2013 (International Telecommunication Union, 2011). In 2006, Kazakstan adopted a program of reducing information and digital inequality/divide where ICT is considered to be a strategic tool for economic growth that provides businesses with a competitive advantage by increasing the efficiency of operations. The program aimed to reach $20 \%$ computer Internet literacy by 2009 as well as to increase the social and economic importance of ICTs (Electronic government of the Republic of Kazakhstan, 2007). According to recent data, the usage of ICT increased by $26 \%$. PC usage increased by $38.5 \%$ and Internet usage was raised by $49 \%$. Interestingly, mobile phone diffusion is very high-100 to $130 \%$ depending on the statistic agency. BuddeCom gives 21 million subscribers for the mobile phone services (2012). 
Table 6. PC penetration and Internet adoption by different agencies.

\begin{tabular}{|c|c|c|}
\hline Agency & $\begin{array}{c}\text { PC, Internet Adoption } \\
\text { (\% population) }\end{array}$ & $\begin{array}{c}\text { Mobile Phone Adoption } \\
\text { (\% population) }\end{array}$ \\
\hline GISWatch & 15 & - \\
\hline CIA The World Factbook & 30 & - \\
\hline Internet World Stats & 34 & 123 \\
\hline KZ Stat Agency & 7 (Internet subscribers) & 130 \\
\hline BuddeCom & 16 (Internet subscribers) & \\
\hline
\end{tabular}

In the presented study all respondents emphasized that PC and the Internet penetration in the country is still in its infancy. Among the factors slowing ICT adoption, business respondents pointed to high cost and low-speed Internet. Just getting online for a business can cost between $\$ 111$ and \$22,000 a month, depending on the desired connection speed and not including hardware. The average monthly wage in Kazakhstan is just \$399. That means large swaths of the population are cut off from the online world completely. The high cost can be explained by the fact that there is only one major Internet provider in this country KazakhTelecom. However, KazakhTelecom doubled Internet speed by the end of 2011 (Tengrinews.kz, 2011a).

Those who do find their way onto the net face a number of restrictions in what they can publish. According to marketingvox.com (2007a), Kazakhstan residents face both very high Internet access costs as well as restrictions on their online publishing freedoms. The government often slows down the loading speed of pages it finds offensive to discourage visitors (marketingvox.com, 2007b). Censorship of the Internet recently enforced by the government was also named by the respondents as a factor having a negative impact on the ICT adoption and usage.

Kazakhstan's Ministry of Communications and Information has set a goal to raise Internet speed to 16 Mbit per second in three years' time (Tengrinews.kz, 2011b). Now 4G is available in some major Kazakhstan cities. In 2011, it was reported that this particular format is available in 20 cities of Kazakhstan.

There are considerable differences in ICT adoption between big cities and rural areas: major cities such as Almaty and Astana show high Internet and PC adoption, but there is very slow PC/Internet adoption in rural areas. According to the interviewees, consumers in rural areas do not have access to PCs, nor are they connected to the Internet. Pronounced differences in ICT adoption were also noted between different age groups. People in the 1825 year age bracket were much more comfortable with the technology than older generations. 
Interviewees pointed out that similar differences exist between different social strata with higher incomes predicting an earlier adoption of the technology. On the basis of the obtained data, an early adopters profile was formulated: up to 25 years old, city dweller, above average income bracket, white-collar or student. Early adaptors are also PC owners, Internet adopters and mobile phone(s) owners. The Internet for them is a mainstream medium mainly used for information search.

In our previous pilot research on the comparison of the Russian, Ukrainian and Kazakh markets, considerable similarities in ICT adoption by the younger generation (student or white-collar, 18-35 years old) were found (Rubina and Garkavenko, 2009). Similar to the previous study, it was established that this group of prospective consumers was characterized by a positive attitude towards the Internet. They perceived themselves as very confident ICT users who have no problem searching the Internet for information. However, there were some strong reservations regarding buying online. The privacy issues, security and difficulty of the shopping process were found to be the main reasons for being wary about using the Internet for shopping. It was also shown that there was no association between any of the demographic variables including gender, income, and attitude towards the Internet in general, and shopping online in particular. This group is characterized by a high level of ICT adoption including the Internet and mobile Internet. It was concluded that e-commerce and mcommerce have a great potential with the young generation of students and young professionals in those three markets.

However, the respondents in the present study pointed out the existence of limiting factors in ICT adoption. Specifically regarding the purchase and booking of travel products on-line, it was pointed out by the interviewees that heterogeneity of Internet adoption within the population is a limiting factor for the development of e-commerce. Another important limiting factor is a banking system that does not support on-line purchasing. Credit card transactions are poorly regulated; the banks do not take any responsibility for unauthorized transactions and put limits on on-line transactions. For instance, the credit card from the Popular Bank (Narodnij Bank) imposed a limit for on-line transactions of 200 dollars. It is obvious that most airfares cannot be purchased within this limit. The most popular sites for shopping are www.homeshop.kz.

The most popular algorithm in searching for information on a destination is through social forums (http://ct.kz (tsentr tiazhesti), http://vk.com (v kontakte), http://yvision.kz). The most popular site for purchasing airfares is the Air Astana website. The interviewees pointed out that the website is user friendly and provides a wide range of services. The Air Astana website (www.airastana.com) was awarded "the best Kazakh site" in 2009. However, the very group who are the most advanced technology users (younger than 25 years and eligible for 
the special category of tickets for young people) is prevented from making such a purchase online. This cheaper fare category can be purchased only through travel agents. According to the respondents, bookings and ticketing through agents will continue and this situation is not likely to change in the near future.

Similarly to the official statistic data interviewees in the presented study talked of very high mobile phone adoption. According to the respondents, "Everyone has a mobile phone." There was no noted disparity between rural and urban areas for mobile phone adoption.

\subsection{CONCLUSIONS}

The Travel industry is an information intensive one. With the adoption of the Information and Communication Technologies (ICT), and the Internet, in particular, both the distribution chain and the way of doing business have changed. The Internet connects all players directly - airlines, tour operators, travel agents and their consumers, and in this way ICT has become a catalyst of travel industry globalization and integration. However, it has been noted that digital disparities between destinations leads to an asymmetrical development of the global tourism system (Mingetti and Buhalis, 2010). The research on the digital divide in tourism would help to identify appropriate actions to bridge the digital gaps and to develop communication mechanisms between digitally excluded markets, destination and businesses.

There is a little academic and business research on ICT adoption by the Kazakhstan tourism industry (Garkavenko et al., 2009a,b; 2010a,b; Garkavenko and Tiberghien, 2011a,b; 2012). Our previous studies showed considerable disparities between travel industry sectors and businesses within a sector in terms of ICT adoption. The presented study summarizes the ICT adoption by the Kazakhstan tourism industry and consumers using both secondary and primary data. The original exploratory study adopts qualitative methods to seek a holistic understanding of the under-investigated Kazakhstan travel industry.

It was found that the level of ICT adoption by the travel industry in Kazakhstan is variable within the different sectors and between different businesses within one sector, and generally is much lower compared to that of western countries. As one would expect, airlines were the earliest adopters of ICT and they are fully integrated with the international airline network. The hotel industry, however, varies in ICT adoption. The biggest hotels are part of major international chains and keep their systems up to international standards. Small hotels however, are not as motivated in ICT implementation - some of them prefer to connect directly with travel agents to attract tourists, and they do not have any web presence. Regarding tour operators, ICT adoption is restricted to one particular GDS-Amadeus. The travel agents' sector is the biggest sector of the tourism industry in Kazakhstan by the number of businesses. It also varies in the level of ICT adoption - there is a group of TAs that has 
invested in the GDS system (again Amadeus only) to purchase tickets or to have access to international hotel bookings. Partially they use the Internet for the B2B model, for instance to sell tickets to smaller non-GDS-connected agencies. The majority of travel agencies consist of small businesses (less than 10 employees) that do not have access to any GDS and their usage of ICT is limited to simple e-mails and phones. The majority of them have websites, but TAs are mainly concerned with a web presence rather than website performance. Consumers in their interviews complained about the lack of ICT-savvy tourism specialists. The study reveals that, overall, the Kazakhstan tourism industry is a laggard in ICT adoption.

Consumers' in-depth interviews revealed interesting trends in ICT diffusion. There are considerable geographical, social and age disparities in ICT adoption and perception of Kazakhstan consumers. The early adopters' profile was formulated as a result of the research: up to 25 years old, city dwellers, above the average income bracket, white-collar or students. Privacy issues, security and complexity of the shopping sites were identified as the main barriers for the shopping on-line. High Internet cost, low broadband speed, censorship of the Internet post were barriers for the Internet adoption and further diffusion. Official statistics gives different figures for ICT diffusion in general population-from 15 to $34 \%$. Interestingly both official statistics and primary data indicate a very high level of mobile diffusion-more than $100 \%$. We concluded that mobile phones are the potential media to reach prospective consumers.

\section{KEYWORDS}

\section{REFERENCES}

American Airlines. (2000). American Airlines Web site. Retrieved April 3, June 14, August 20, 2000, from http://www.aa.com/.

Aneshensel, C. S. (2002). Theory-based data analysis for the Social Sciences. Thousand Oaks, California: Pine Forge Press.

Beeton, S. (2005). The case study in tourism research: A multi-method case study approach.

In B. W. Ritchie (Ed.), Tourism Research Methods: Integrating Theory With Practice (pp. 37-48). Oxford: Oxford University Press.

BuddeCom. (2012). Kazakhstan-Telecoms, Mobile, Broadband and Forecasts. Retrieved 16/05/2012 from https://www.budde.com.au/Research/Kazakhstan-TelecomsMobile-Broadband-and-Forecasts.html?r=51.

Buhalis, D. (1998). Strategic use of information technologies in the tourism industry. Tourism Management, 19(5), 409-421. 
Buhalis, D. (2000a). Conference report: Distribution channels in the changing travel industry. The Dorchester, London, 9-10 December 1998. International Journal of tourism research, 2(2), 137-139.

Buhalis, D. (2000b). Tourism and information technologies: Past, present and future. Tourism Recreation Research, 25(1), 41-58.

Buhalis, D. (2003). eTourism: Information Technology for Strategic Tourism Management. Harlow, England: Pearson Education.

Buhalis, D. (2004). eAirlines: Strategic and tactical use of ICTs in the airline industry. Information \& Management, 41, 805-825.

Dean, A., Morgan, D., Tan, T. E. (2002). Service quality and customers' willingness to pay more for travel services. Journal of Travel \& Tourism Marketing, 12(2/3), 95110.

www.economist.com. (2005). Flying from the computer: The Internet has pitted travel agents against travel providers in an intense battle to win customers. economist.com, Special Report, Sep 29th 2005. Retrieved 04.10.2005, from http://www.economist.com/displaystory.cfm?story_id=4455692

Electronic government of the Republic of Kazakhstan. (2007). Program for Bridging Digital Divide in the Republic of Kazakhstan 2007 to 2009. Retrieved 26/04/2011 from http://egov.kz/wps/portal/Content?contentPath=/library2/extra/all\%20egov/proje ct\%20egov/sin\&lang=en.

eMarketer. (2009). US Internet users. Accessed on 20/03/09 at www.emarketer.com/Reports/All/Emarketer_2000561.aspx.

European Travel Commission. (2006). Asia Pacific. New Media Review (ETC CET)-\& Regional Overview, 26 May. Retrieved 1/06/2006, from http://www.etcnewmedia.com/review/default.asp?SectionID=10\&CountryID=34

Flyvbjerg, B. (2006). Five misunderstandings about case-study research. Qualitative Inquiry, 12(2), 219-245.

French, T. (1998). The future of global distribution systems. Travel \& Tourism Analyst, 3, 117.

Garkavenko, V., Milne, S. (2008a). New Zealand Travel Agents in the Internet Era: Spatial Differences in ICT Impact, Adoption and Perception. In O'Connor P, Hopken W, Gretzel U. (Eds.), Information and Communication Technologies in Tourism-2008. Springer Wien: New York, 298-307. 
Garkavenko, V., Milne, S. (2008b). ICT and the travel industry: Opportunities and challenges for the New Zealand travel agents' market. In C. Van Slyke (Ed.), Information Communication Technologies: Concepts, Methodologies, Tools and Applications. Hershey, PA: IGI Global.

Garkavenko, V., Surnina, S., Tiberghien, G., Gimranova, D. (2009a). Kazakhstan’s Travel Agent Sector: Main Issues, Impacts and Relationships. VI KIMEP International Research Conference (6th KIRC), 23-24 April, Almaty, Kazakhstan.

Garkavenko, V., Surnina, S., Tiberghien, G., Gimranova, D. (2009b). ICT impacts on the Kazakhstan travel industry. VI KIMEP International Research Conference (6th KIRC), 23-24 April, Almaty, Kazakhstan.

Garkavenko, V., Tiberghien, G., Gimranova, D. (2010a). Kazakhstan Travel Market and ICT Readiness: Consumer Dimension. VII KIMEP International Research Conference (7th KIRC), March 25-27, 2010, Almaty, Kazakhstan.

Garkavenko, V., Tiberghien, G., Surnina, S., Gimranova, D. (2010b). Information and communication technologies: Kazakhstan travel market perspective. Proceedings of ENTER 2010-Information and Communication Technologies in Tourism. The 17th International Conference on Information Technology and Travel \& Tourism IFITT's Global Travel \& Tourism Technology and eBusiness Forum. 10th-12th February 2010, Università della Svizzera Italiana, Lugano Switzerland.

Garkavenko, V., Tiberghien G. (2011a). Information and communication technologies adoption by the Kazakhstan travel market. Proceedings of Eurasia Business and Economics Society (EBES) 2011 Conference-Istanbul, June 1-3, 2011, Istanbul, Turkey.

Garkavenko, V., Tiberghien G. (2011b). Kazakhstan's travel industry: its history, current structure, and perspective for global integration. Proceedings of the World Research Summit for Tourism and Hospitality, 10-13 December 2011, Hong Kong.

Garkavenko, V., Tiberghien, G. (2012). Kazakhstan's travel industry: past and futureperspective for global integration. Proceedings of IX KIMEP International Research Conference (9th KIRC), April 19-21, 2012, Almaty, Kazakhstan.

Horner, S., Swarbrooke, J. (2004). International Cases in Tourism Management. Oxford: Elsevier Butterworth-Heinemann.

International Telecommunication Union. (2011). Measuring the Information Society 2011. Geneva: ITU. 
Kadyrova, D., Maratov, A., Bolatbekuly, O., Laulanov, A., Gimranova, D., Garkavenko, V. (2011). The ICT development Index in Kazakhstan: The Focus on Business Environment. Proceedings of VIII KIMEP International Research Conference (8th KIRC), April 22-23, Almaty, Kazakhstan.

Karin von Abrams. (2008). France's e-tailers upbeat. eMarketer. Accessed 20/03/09 at www.Emarketer.com/Article.aspx?id=1006949.

Kirby, M. (2001, May 22). Orbitz boasts healthy prelaunch statistics. Air Transport Intelligence News, Washington, DC.

Kwortnik, R. J. (2003). Clarifying fuzzy consumer-research problems with depth interviews and qualitative analysis. Cornell Hotel and Restaurant Administration Quarterly, 44 (April), 117-129.

Marcussen, C. H. (2004). Trends in the European Internet distribution—of travel and tourism services. Report, 27 May 2004. Retrieved 9/06/2004, from http://www.crt.dk/uk/staff/chm/trends.htm.marketingvox.com. (2007a). Internet Censorship Strengthens in Malaysia, Kazakhstan and Other Countries. Retrieved 16/09/2011 from http://www.marketingvox.com/Internet-censorshipstrengthens-in-malaysia-kazakhstan-and-other-countries031803/.marketingvox.com. (2007b). Kazakhstan's Internet Access Not Very Nice. Retrieved 17/09/2011 from http://www.marketingvox.com/kazakhstansInternet-access-not-very-nice-031795/.

Mason, D., Milne, S. (2002). E-Commerce and Community Tourism. In: P. C. Palvia, S. C. Palvia \& E. M. Roche (Eds.), Global Information Technology and Electronic Commerce: issues for the New Millenium (pp. 294-310). Marietta, Gerogia: Ivy League Publishing Ltd.

Minghetti, V., Buhalis, D. (2010). Digital Divide in Tourism. Journal of Travel Research, 49(3) $267-281$.

Morrisette, S., Gazala, M. E., Green, E. N., Reitsma, R., Metzger, T. (1999). Europe's digital decade. The Forrester Report Quick View, November 1999. Retrieved July 23, 2000, from http://www.forrester.com/

O’Brien, P. F. (1999). Intelligent Assistants for retail travel agents. Information Technology \& Tourism, 2(3/4), 213-228.

O’Brien, P. F. (2002). An architecture for ubiquitous travel service delivery. Paper presented at the European Conference on Information Systems, Gdansk, Poland.

O’Connor, P. (1999). Electronic information distribution in tourism and hospitality. Wallingford: CABI Publishing. 
O’Connor, P., Frew, A. J. (2002). The future of hotel electronic distribution: expert and industry perspectives. Cornell Hotel and Restaurant Administration Quarterly, 43(3), 33-45.

Oppenheim, A. N. (1992). Questionnaire Design, Interviewing and Attitude Measurement (2nd ed.). New York: Continuum.

Organization for Economic Cooperation and Development (OECD). (2001). Understanding the Digital Divide. Paris: OECD.

Poon, A. (1993). Tourism, Technology and Competitive Strategies. Oxford: CAB International.

ROMIR Monitoring. (2009). Russian Internet Advertising Report. Accessed 20/03/09 at www.mediarevolution.ru/english/231.html.

Rubin, H. J., Rubin, I. (2005). Qualitative Interviewing : The Art of Hearing Data (2nd ed.). Thousand Oaks, California: Sage Publications.

Rybina, L., Garkavenko, V. (2009). Internet adoption by prospective consumers: example of Kazakhstani, Russian and Ukrainian markets. VI KIMEP International Research Conference (6th KIRC), 23-24 April, Almaty, Kazakhstan.

Selwyn, N. (2004). Reconsidering Political and Popular Understandings of the Digital Divide. New Media Society, 6(3), 341-362.

Seymour, W. S. (2001). In the flesh or online? Exploring qualitative research methodologies. Qualitative Research, 1(2), 147-168.

Silverman, D. (Ed.). (2004). Qualitative Research: Theory, Method and Practice (2nd ed.). London: SAGE Publications.

Smith, C., Jenner, P. (1998). Tourism and the Internet. Travel \& Tourism Analyst, 1, 62-81.

Tengrinews.kz. (2011a). KazakhTelecom introduces new Internet tariffs from 1 October 2011. Retrieved 10/12/2011 from http://tengrinews.kz/kazakhstan_news/kazahtelekom1-oktyabrya-zapuskaet-novyie-tarifnyie-planyi-Internet-polzovateley-197968/.

Tengrinews.kz. (2011b). Internet speed in Kazkahstan to reach 16 Mbit per second by 2014. Retrieved 04/03/2012 from http://en.tengrinews.kz/Internet/Internet-speed-inKazkahstan-to-reach-16-Mbit-per-second-by-2014-1126/.

Tiberghien, G., Garkavenko, V. (2011). Exploratory study on contributions of Information and Communication Technologies to the development of ecocultural tourism in Central Kazakhstan. Proceedings of ENTER 2011-Information and Communication Technologies in Tourism. The International Conference on Information Technology and Travel \& Tourism IFITT's Global Travel \& 
Tourism Technology and eBusiness Forum. 26th-28th January 2011, Innsbruck, Austria.

Tse, A. C.-B. (2003). Disintermediation of travel agents in the hotel industry. International Journal of Hospitality Management, 22, 453-460. 